\title{
Acceptance of the sense of implementing safe fall programs for people with visual impairments or after amputation of limbs - the perspective of modern adapted physical activity
}

\author{
Gąsienica Walczak B. ${ }^{\mathrm{ABCDE}}$ \\ Podhale State College of Applied Sciences in Nowy Targ, Poland
}

Authors' Contribution: A - Study design; B - Data collection; C - Statistical analysis; D - Manuscript Preparation; E-Funds Collection.

\begin{abstract}
Purpose: $\quad$ The aim of the study was to find out whether safe falling programs for patients with visual impairment or limb amputees, as a prospective modern adapted physical activity, gained acceptance from physiotherapy students and people with disabilities.

Material: $\quad$ The study consisted of three stages. The sample included 189 participants. The preset inclusion criterion (adequate attendance during the training) was met by 134 students and all the participants with visual impairment $(n=6)$ and after limb amputation $(n=8)$.

Results: $\quad$ The opinions that implementation of STSFT programs for patients with visual impairment or after limb amputation, expressed by physiotherapy students (about $94 \%$ and $95 \%$ of students at stages I and II respectively) and patients with disabilities ( $100 \%$ of amputees and $83 \%$ of patients with visual impairment at stage III), who learned to protect their bodies during collisions with the ground, indicate that the aforementioned empirically verified programs are effective.

Conclusions: 1. Implementation of safe falling programs as an adapted physical activity for patients with visual impairment or after limb amputation may adversely affect their feeling of safety and motivation for practicing sports, tourism or other physical activities. 2. Physiotherapy students specializing in safe falling will contribute to a growing number of new workplaces and innovative services, both for able-bodied people and people with disabilities. Such a specialty will be essential for public health including improvement of the patient's quality of life.

Keywords: $\quad$ susceptibility to body injuries during the fall, health-focused training, theory and methodology of safe falls courses.
\end{abstract}

\section{Introduction}

Falls are a major public health problem worldwide. Every year 37 million of falls are noted and the consequences are so severe that the patients require medical intervention and 646 people die from falls every year [1]. According to World Health Organization definition a fall is: "inadvertently coming to rest on the ground, floor or other lower level, excluding intentional change in position to rest in furniture, wall or other objects" [2]. American Geriatric Society (AGS) or British Geriatric Society (BGS) define a fall as: „an event whereby an individual unexpectedly comes to rest on the ground or another lower level without known loss of consciousness." [3]. According to Polish school of safe falling (Jaskólski and Nowacki [4] and Kalina [5]) fall is "a controlled motor activity ensuring optimal protection of the body when falling on the ground or, under certain circumstances, minimizing damage or death prevention". According to this definition, there are two types of incidents, namely: 1) "sudden loss of balance (especially due to external forces), e.g. on a slippery surface, when a trained person immediately controls both his/her individual body parts according to falling direction or under other important circumstances (e.g. when stumbling against objects, etc.)" 2) "a deliberate fall or a motor response to sudden threat identified by

(c) Gąsienica Walczak B., 2019

doi:10.15561/20755279.2019.0603 the falling person, to prevent undesired consequences". The behaviors described under both circumstances will be impossible when a person who falls from a high place losses consciousness and therefore, is unable to control his or her body properly [6]. The definitions cited above differ, yet they share some elements.

Many groups of people at high risk of falling have been identified. These include people with disabilities (after limb amputation, with visual impairment including blindness, etc.), especially those with poor mobility who are obviously at risk of body injuries associated with falls. It is essential, especially for these individuals to participate in sessions of exercise-based adapted physical activity (APA) including the following training elements: improving their postural stability (muscle strength, flexibility and balance) and locomotion; enabling safe contact with surface after losing body balance or collisions with various obstacles; avoiding collisions with moving objects (e.g. cars in motion) [7-11]. There should be no barriers for their participation in APA, such as their degree of disability or motor impairment. Contrary, they should be motivated to improve their motor abilities to provide effective protection for their bodies in cases of balance loss when falling onto the ground or during collision with vertical objects.

The cited definitions are the main prerequisites for implementation of two sorts of programs including fall prevention and the consequences of falling. The former 
comprise fall reduction programs based on definitions developed by WHO, AGS, BGS [e.g.: 12-17]. The aim of these programs is to eliminate risk factors for falls through improvement of muscle mass, balance and coordination as well as spatial orientation, identifying the circumstances when the risk of falls is elevated (e.g. black ice), and by selection of adequate clothes, motor behaviors, etc. Sheer et al. [18] in their study carried out a systematic paper review (29 papers) on fall prevention programs. The interventions involved gait and balance training and functional training $(72 \%)$, muscle strength training $(72 \%)$, general physical activity (41\%), flexibility (28\%) and endurance (21\%). Hill et al. [19] studied 26 fall prevention programs implemented in Asia. Most of them were based not only on training of muscle strength, flexibility and balance, but also on environmental modification, educative sessions and medication use (vitamins: K2 and D3). The adaptive effect of multifactor intervention programs involved a reduced risk of falls (depending on the program), merely from $15 \%$ to $48 \%$. This finding suggests that the risk of falling in persons who do not observe prevention rules is as high as $52-85 \%$ (which entails the risk of body injuries).

Safe falling programs are the solutions that may reduce injury risk. The empirically verified programs developed by Polish researchers and practitioners [20] are dedicated to healthy persons of all ages as well as limb amputees, patients with visual conditions, obese persons and patients with osteoporosis and neural disorders. Rafał Kubacki has popularized the safe falling program using Swiss ball [21]. Spanish researchers [22] described the effects of teaching how to protect one's body during rear falls among school-age children. The children learned how to protect their body parts during rear falls: $89 \%$ of children correctly controlled their "neck" while $85 \%$, $99 \%, 100 \%$ and $99 \%$ correctly controlled their "trunks", "knees", "hips" and "hands" respectively.

The well documented scientific knowledge acquired at the Polish School of Safe Falling [from the theory [4] to empirically verified programs dedicated to healthy people [5, 8, 23-26] and Roman Maciej Kalina's experience in methodology, documented with his first publication in 1976 [27] were the basic prerequisites for the implementation of tailored courses on theory and methodology of safe falls (based on the programs dedicated to people with disabilities), implemented in the academic year 2009/2010 at Physiotherapy Department of Podhale State College of Applied Sciences (PSCAS) in Nowy Targ. The first program (TMSF1) is focused on teaching rear falls and falls to the side in patients with visual impairment; the second one (TMSF2), has been developed for limb amputees (additionally including front falls and front falls with turn over a shoulder).

Study aim. The aim of the study was to find out whether safe falling programs for patients with visual impairment or limb amputees, as a prospective modern adapted physical activity, gained acceptance from physiotherapy students and people with disabilities.

\section{Material and Method}

Participants. The study consisted of three stages. The sample included 189 participants. The preset inclusion criterion (adequate attendance during the training) was met by 134 students and all the participants with visual impairment $(\mathrm{n}=6)$ and after limb amputation $(\mathrm{n}=8)$.

\section{Stage I. Pilot study}

In the first, pilot study, 113 third year physiotherapy students from Podhale State College of Applied Sciences (PSCAS) in Nowy Targ (84 women and 29 men: stage I;2009/2010) were assessed. The survey was carried out at the end of December 2009 (on completion of TMSF1 course). The results obtained from 68 women and 22 men, who met the preset attendance criterion (90-100\%) during the pilot study, were subjected to analysis (Table 1).

During the first stage of the study the training was divided into two separate courses. The first course (TMSF1) comprised rear falls and falls to the side according to the methodology of teaching for visually impaired patients. It consisted of 10 training and methodology sessions including: 45 minutes of exercise, 45 minutes of methodical problem solving, overall ten 90-minute sessions. Additionally, it included five 90-minute lectures. The second course (TMSF2) comprised teaching methods for patients after limb amputation and involved training of rear falls and falls to the side, and additionally, learning front falls and front falls with turn over a shoulder. The structure of the course was identical to that of the first course.

The topics of the lectures included: epidemiology and prevention of body injuries due to falls and collision; safe

Table 1. The age and somatic characteristics of physiotherapy students obtained from the first stage of the research

\begin{tabular}{|c|c|c|c|c|c|c|c|c|c|c|c|c|}
\hline \multirow{4}{*}{ Variable (index) } & \multicolumn{12}{|c|}{ Age and somatic characteristics } \\
\hline & \multicolumn{12}{|c|}{ Group with $90-100 \%$ attendance $(n=90)$} \\
\hline & \multicolumn{2}{|c|}{$\mathrm{x}$} & \multicolumn{2}{|c|}{ SD } & \multicolumn{2}{|c|}{$\min$} & \multicolumn{2}{|l|}{$\max$} & \multicolumn{2}{|c|}{ kurtosis } & \multicolumn{2}{|c|}{ Skewness } \\
\hline & $\begin{array}{l}K \\
(n=68)\end{array}$ & $\begin{array}{l}M \\
(n=22)\end{array}$ & $\begin{array}{l}K \\
(n=68)\end{array}$ & $\begin{array}{l}M \\
(n=22)\end{array}$ & $\begin{array}{l}K \\
(n=68)\end{array}$ & $\begin{array}{l}M \\
(n=22)\end{array}$ & $\begin{array}{l}K \\
(n=68)\end{array}$ & $\begin{array}{l}M \\
(n=22) \\
\end{array}$ & $\begin{array}{l}K \\
(n=68)\end{array}$ & $\begin{array}{l}M \\
(n=22)\end{array}$ & $\begin{array}{l}K \\
(n=68)\end{array}$ & $\begin{array}{l}M \\
(n=22)\end{array}$ \\
\hline Age (years) & 21.2 & 22.0 & 0.7 & 2.8 & 20 & 21 & 25 & 34 & 15.56 & 18.63 & 3.52 & 4.20 \\
\hline Body height $(\mathrm{cm})$ & 167.4 & 180.4 & 5.6 & 4.8 & 153 & 170 & 180 & 191 & 0.01 & 0.13 & 0.04 & 0.08 \\
\hline Body mass (kg) & 57.9 & 75.7 & 7.1 & 7.2 & 43 & 65 & 78 & 90 & -0.23 & -0.75 & 0.21 & 0.53 \\
\hline BMI & 20.7 & 23.3 & 2.2 & 2.0 & 16.4 & 20.1 & 28.1 & 27.8 & 1.4 & -0.5 & 0.7 & 0.5 \\
\hline
\end{tabular}


falling theory; approaches to diagnosing susceptibility to body injuries during falls and motor competences of safe falling; specificity, safety conditions and methodology of safe falling teaching in people with various degrees of visual and motor impairment; conception of motor adaptation in safe falling teaching and collision avoidance in patients with different degrees of visual and motor impairment.

\section{Stage II. Core assessment}

The core study included the program extended with fun forms of martial arts [10], additionally considering a higher number and frequency of specific motor simulations [28]. The preset criterion of $80 \%$ attendance (or participation in 8 cyclic training sessions within 10 weeks) was accepted as an optimal organizational criterion and the period necessary for cumulation of the stimuli to obtain the expected adaptive effects.

The sample included 62 (42 women and 20 men third-year physiotherapy students from PSCAS in Nowy Targ (2010/2011). The accepted attendance criterion (80$100 \%$ ) was met by 30 women and 14 men (Table 2).

The core study was carried out in a room bigger than the one used during the pilot study. During that stage, the educational aids additionally included protective helmets used in kickboxing, orthosis, orthopedic crutches and walking sticks. The structure of the course was identical to that of the pilot study. At that stage, the students were randomly paired. When the first participant in a pair performed motor tasks (the participant was treated like a patient), the second one was responsible for protection, assistance, safety and providing information about progress and errors (the therapist's role); the tasks were identical to those verified during stage I (as was the content of the presented lectures).
The study was conducted within the research projects: Resolution No. 3/02/2011 Bioethics Committee at the Rzeszow University, Rzeszow, Poland.

The survey was conducted at the end of December 2010 (on completion of TMSF1course and at the end of May 2011 (on completion of TMSF2 course).

Stage III. Clinical assessment

During the third stage, 6 students who reached maturity (1 woman and 5 men) from the Special Purpose School and Education Center for Blind and Purblind Children in Cracow were assessed. The survey was carried out at the beginning of February 2014 and at the end of June 2014. Additionally, 8 football players from AMP-football Krakow sports club were subjected to clinical assessment. The survey was conducted at the beginning of June 2015 and at the end of September 2015.

The clinical assessment of the patients with visual impairment was performed as a single course, consisting of 10 therapeutic training sessions (from 30 to 45 minutes) held once a week in a form of physical education classes. The patients learned rear falls and falls to the side (right and left). In order to assure optimum safety of the workout, maximum 4 patients with visual impairment took part in the session. The training was carried out in the gym. Each patient performed exercises using minimum two big (closely aligned) mattresses.

Assessment of the patients after limb amputation was carried out as a single course consisting of 10 therapeutic training sessions (lasting 30 to 45 minutes each), once a week during the warm up preceding the football training. They learned how to perform rear falls with turn over the shoulder and falls to the side (left and right). In order to provide maximum safety, the footballers trained in turn (four footballers performed workout at the same time).

Table 2. Age and somatic characteristics of the physiotherapy students during the second stage of the study.

\begin{tabular}{|c|c|c|c|c|c|c|c|c|c|c|c|c|}
\hline \multirow{3}{*}{$\begin{array}{l}\text { Variable } \\
\text { (index) }\end{array}$} & \multicolumn{12}{|c|}{$\begin{array}{l}\text { Age and somatic characteristics } \\
\text { Group with } 80-100 \% \text { attendance }(n=44)\end{array}$} \\
\hline & \multicolumn{2}{|l|}{$x$} & \multicolumn{2}{|l|}{ SD } & \multicolumn{2}{|l|}{$\min$} & \multicolumn{2}{|l|}{$\max$} & \multicolumn{2}{|c|}{ Kurtosis } & \multicolumn{2}{|c|}{ Skewness } \\
\hline & $\begin{array}{l}K \\
(n=30)\end{array}$ & $\begin{array}{l}M \\
(n=14)\end{array}$ & $\begin{array}{l}K \\
(n=30)\end{array}$ & $\begin{array}{l}M \\
(n=14)\end{array}$ & $\begin{array}{l}K \\
(n=30)\end{array}$ & $\begin{array}{l}M \\
(n=14)\end{array}$ & $\begin{array}{l}K \\
(n=30)\end{array}$ & $\begin{array}{l}M \\
(n=14)\end{array}$ & $\begin{array}{l}K \\
(n=30)\end{array}$ & $\begin{array}{l}M \\
(n=14)\end{array}$ & $\begin{array}{l}K \\
(n=30)\end{array}$ & $\begin{array}{l}M \\
(n=14)\end{array}$ \\
\hline Age (years) & 21.4 & 21.1 & 0.8 & 0.5 & 20 & 20 & 24 & 22 & 2.99 & 2.92 & 1.30 & 0.31 \\
\hline Body height $(\mathrm{cm})$ & 168.3 & 182.6 & 6.2 & 5.8 & 158 & 172 & 183 & 193 & -0.34 & -0.35 & 0.70 & -0.01 \\
\hline Body mass (kg) & 62.6 & 85.4 & 9.4 & 7.6 & 50 & 69 & 83 & 95 & -0.43 & 0.08 & 0.79 & -0.76 \\
\hline BMI & 22.02 & 25.6 & 2.35 & 2.3 & 18.13 & 23.2 & 28.65 & 30.0 & 1.01 & -1.0 & 1.06 & 0.4 \\
\hline
\end{tabular}

Table 3. Age and somatic characteristics of participants with disabilities during the third stage of the study

\begin{tabular}{|c|c|c|c|c|c|c|c|c|}
\hline \multirow{3}{*}{ Variable (index) } & \multicolumn{8}{|c|}{ Age and somatic characteristics } \\
\hline & \multicolumn{4}{|c|}{ Participants with sight defects $(n=6)$} & \multicolumn{4}{|c|}{ Participants after limb amputation $(n=8)$} \\
\hline & $x$ & SD & $\min$ & $\max$ & $x$ & SD & $\min$ & Max \\
\hline Age (years) & 18.5 & 0.8 & 18 & 20 & 31.8 & 6.4 & 24.0 & 44.0 \\
\hline Body height $(\mathrm{cm})$ & 170.3 & 11.2 & 161 & 191 & 177.3 & 7.8 & 165.0 & 190.0 \\
\hline Body mass (kg) & 65.7 & 12.6 & 50 & 86 & 81.0 & 18.4 & 56.0 & 108.0 \\
\hline BMI & 22.7 & 4.8 & 18.6 & 32.0 & 25.6 & 4.5 & 19.8 & 33 \\
\hline
\end{tabular}


The training was performed on the playground with an artificial surface (soft surface, therefore mattresses were not used).

The study (regarding clinical observations) was conducted within the research projects: Resolution No. 04/2013 Bioethics Committee at the Jerzy Kukuczka Academy of Physical Education, Katowice, Poland.

Diagnostic poll approach

On completion of the first course (TMSF1), during the first and the second stage of the study, a questionnaire on the acceptance of the sense of teaching safe fall techniques (STSFT) was distributed among patients with visual impairment. On completion of the second course (TMSF2), during the first and the second stage of the study, a questionnaire was distributed among the students. It provided information on the participants' acceptance of STSFT for patients with visual impairment or after limb amputation. The preset diagnostic criterion was the answer to the following question: Now, when you have completed the course, do you think that teaching safe fall techniques in visually impaired patients or patients after limb amputation makes sense? [a] yes; [b] I don't know; [c] I have some doubts [d] it doesn't make sense.

On completion of the clinical assessment (stage III) the patients with disabilities filled in the questionnaire which provided information on their acceptance of STSFT teaching in patients with the same disabilities (visual impairment or limb amputation). Now, when you have completed the course, do you think that teaching safe fall techniques in visually impaired patients or patients after limb amputation makes sense? [a] yes; [b] I don't know; [c] I have some doubts [d] it doesn't make sense.

Statistical analysis.

The statistical analysis was based on estimation of the empirical variables; the mean values, standard deviations (SDs), the range (minimal and maximal values), skewness and kurtosis were calculated. It was carried out using PQStat version 1.6.8 statistical package. Whether the research data were homogeneous or not was tested with the "Kolmogorov Smirnov". The distribution of values turned out to differ from normal distribution therefore further analyses were conducted using non-parametric approaches. The results were compared using Wilcoxon's signed rank test. The correlations between selected scales were analyzed by estimation of Spearman's rank correlation coefficients. The significance level was set at $\mathrm{p}<0.05$.

\section{Results}

Stage I

On completion of the experiment almost $95 \%$ of all students were convinced that teaching safe fall techniques (STSFT) made sense, both in case of healthy individuals and those from high risk groups (Figure 1).

Stage II

On completion of the experiment over $95 \%$ of the surveyed students were convinced that STSFT in healthy participants and those from the increased risk group made

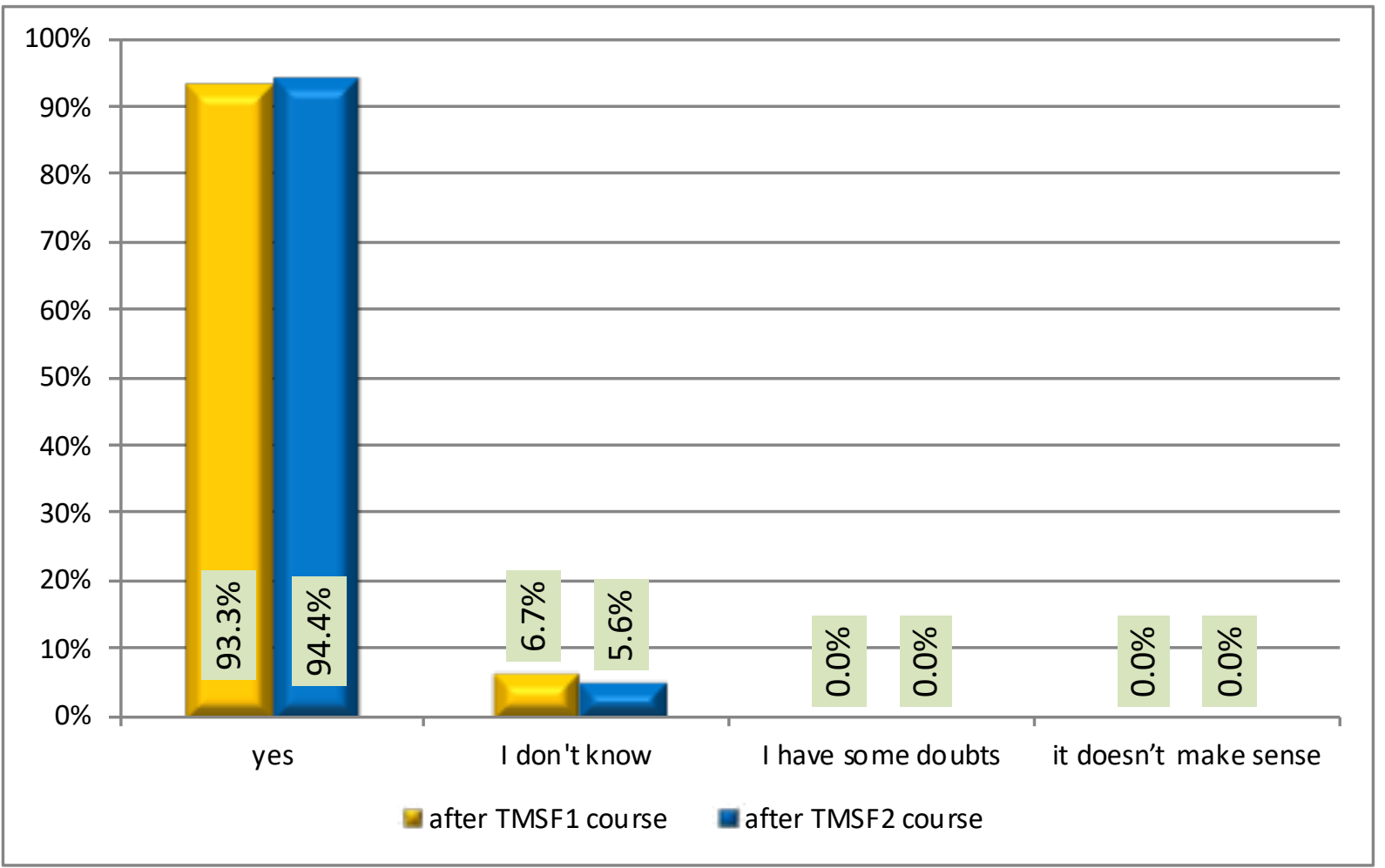

Figure1. The result of STSFT in physiotherapy students $(n=90)$ participating in the first stage of the study (TMSF1 and TMSF2). The question was: Now, when you completed the course the course, do you think that teaching safe fall techniques in visually impaired patients or patients after limb amputation makes sense? [a] yes; [b] I don't know; [c] I have some doubts[d] it doesn't make sense. 


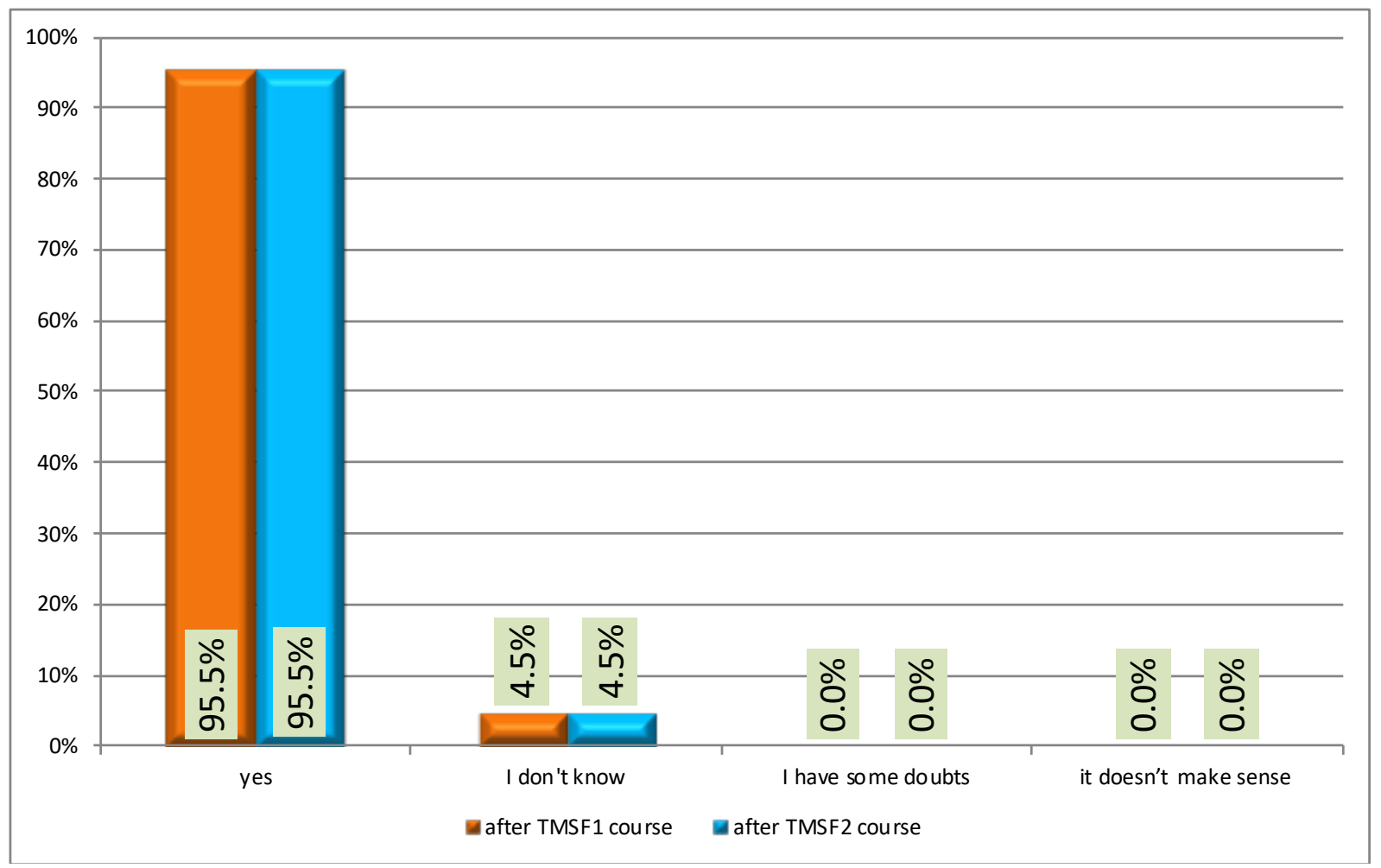

Figure 2. The result of STSFT obtained from physiotherapy students $(n=44)$ participating in the second stage of the study (TMSF1 and TMSF2). The question was: Now, when you have completed the course, do you think that teaching safe fall techniques in visually impaired patients or patients after limb amputation makes sense? [a] yes; [b] I don't know; [c] I have some doubts[d] it doesn't make sense.

sense and none of the students denied it (Figure 2).

Stage III

On completion of the experiment all the amputees and over $83 \%$ of visually impaired patients were convinced that TSFT in the groups with an increased risk of falls made sense. One response from a visually impaired patient $(16 \%)$ was "I don't know" and none of the respondents denied the sense of TSFT (Figure 3).

\section{Discussion}

The opinions that implementation of STSFT programs for patients with visual impairment or after limb amputation, expressed by physiotherapy students (about $94 \%$ and $95 \%$ of students at stages I and II respectively) and patients with disabilities $(100 \%$ of amputees and $83 \%$ of patients with visual impairment at stage III), who learned to protect their bodies during collisions with the ground, indicate that the aforementioned empirically verified programs are effective. The answers obtained from all the persons who participated in the two specialist (stage I and II) courses or kinesitherapy sessions are the most reliable recommendations for widespread education on safe falling techniques, providing an optimal solution in prevention of body injuries due to falls. None of the physiotherapy students (participating in the two stages of the study and none of the patients voluntarily participating in stage III) questioned the sense of safe falling teaching in patients with visual impairment or after limb amputation. The significantly higher level of acceptance of the innovative TSFT program compared with the level of innovative specialty sense acceptance (EKO-AGROFITNESS() from tourism and recreation students at the same academic center (PSCAS in Nowy Targ) is an additional recommendation for TSFT implementation [29].

The World Health Organization (WHO) [1] emphasizes that fall prevention strategies should be focused on education, training, enabling safe conditions, prioritizing assessment of fall consequences and settling successful policies, aimed at risk diminishing (reduction). However, according to Polish School of Safe Falling [4, 6, $20,30]$ combining fall reduction programs with programs aimed at elimination of fall consequences. These goals can be achieved through adapted physical activity (APA) training (for people with disabilities) and health-focused training (for people with no contraindications for physical exercise), based on teaching and developing safe falling techniques and collision avoidance).

Adapted physical activity (APA) is defined by International Federation of Adapted Physical Activity as a „cross-disciplinary body of knowledge directed towards the identification and solution of individual differences in physical activity. It is a service delivery profession and an academic field of study which supports an attitude of acceptance of individual differences, advocates enhancing access to active lifestyles and sport, and promotes innovation and cooperative service delivery programs and empowerment systems. Adapted Physical 


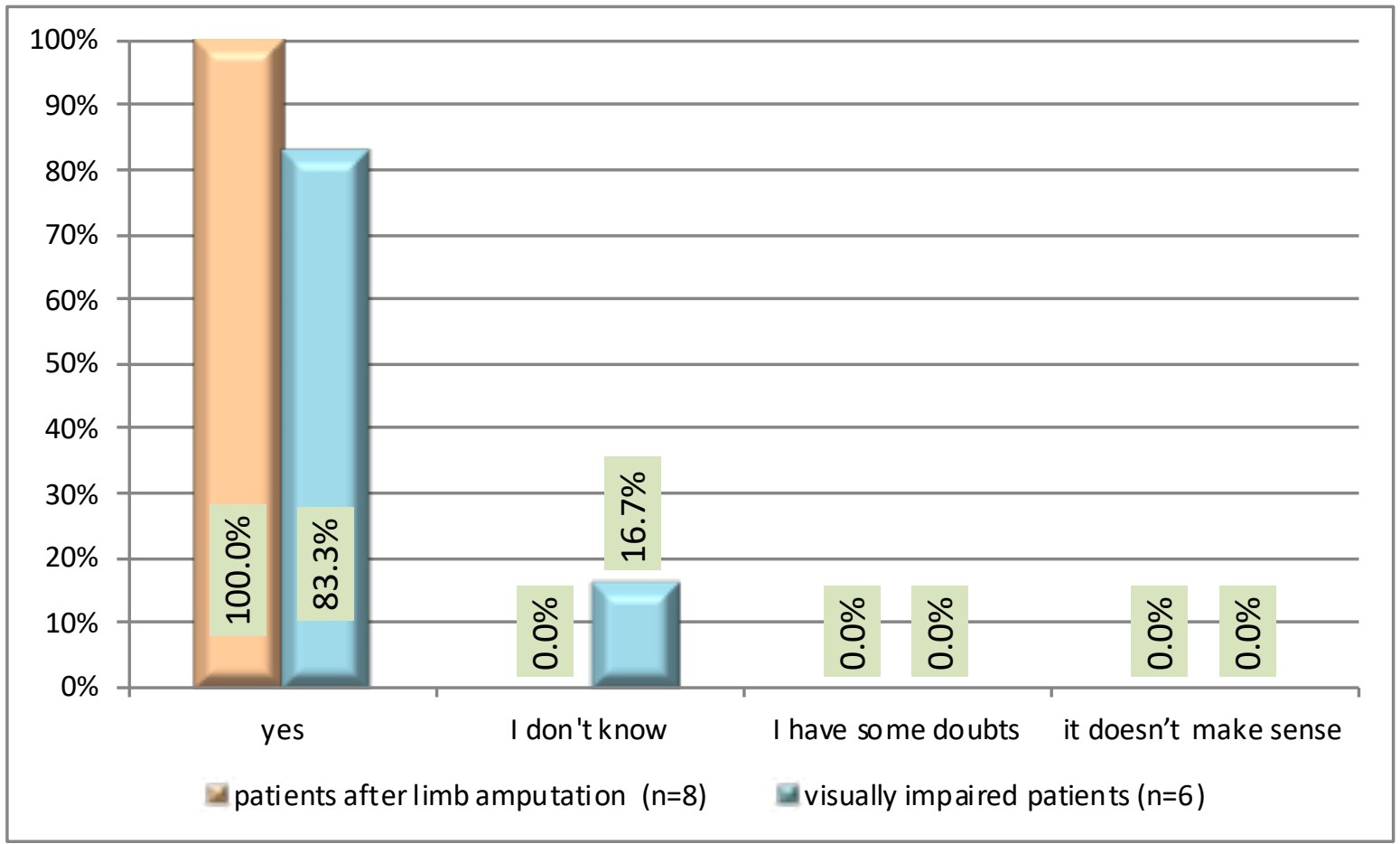

Figure 3. The result of STSFT test in groups at high risk of falling, including visually impaired patients and patients after limb amputation. The question was: Now, when you have completed the course, do you think that teaching safe fall techniques in visually impaired patients or patients after limb amputation makes sense? [a] yes; [b] I don't know; [c] I have some doubts[d] it doesn't make sense.

Activity includes, but is not limited to, physical education, sport, recreation, dance and creative arts, medicine, and rehabilitation" [31]. APA recipients are persons with special needs, namely people with disabilities (in terms of law, biology, and social activities), the elderly, chronically ill individuals, etc. The domains of adapted physical activity may include: rehabilitation, tourism, sport, physical education, health promotion and other forms of motor activity [32], not excluding the prevalence of mental activity offered by innovative agonology [33, $34,35,36]$ or a relatively balanced effect of cognitive and behavioral factors [37]. Safe falling programs (programs eliminating consequences of falls) for people with visual impairment or after limb amputation should be included in the above-cited APA definition. Thanks to such activities, people with disabilities learn to perform controlled motor activities, ensuring optimal body protection (e.g. minimization of lesions). Persons with adverse experience due to the consequences of falling (e.g. fractures, hospitalization, fear for falling again) limit their physical activity as well as their involvement in tourismor sport -related activities. The skills of falling safely can reduce the above limitations and enable participation in active pastimes in many people with disabilities. The evidence is presented by Gąsienica-Walczak et al. [38] who described 10 kinesitherapy sessions based on safe falling training and collision avoidance in 5 males with visual impairment. The assessment of program outcome included the application of susceptibility to body injuries during the fall test (SBIDF) [6], applied before and after 10 sessions of safe falling training. All the participants managed to reduce their susceptibility to injuries through effective control of their key body parts that are most prone to injuries during falls, protecting them against injuries.

The ability to fall safely may contribute to reduction of the number of body injuries and contusions, not only in persons who do not practice any sports, but also in athletes with disabilities. Moilik et al. [39] characterized the injuries sustained by competitive level athletes, involved in the main disciplines included in summer Paralympics. The high risk sports (according to the division by Ferrera et al. [40]) comprised: cycling, horse riding, judo, football, basketball on wheelchairs and rugby on wheelchairs. The authors did not analyze the fall-related injuries, but the sports believed to be risky and thus, inseparably connected with falls. Derman et al. [41] described sport-related injuries during the winter Paralympics in Peyong Chang in 2018. Most of the injuries were noted during para-snowboard competition, next during alpine skiing, hockey on sledge and crosscountry skiing while the fewest injuries were noted during curling on wheel-chairs. As before, the authors did not analyze the fall-related injuries. They reported, however, that the athletes practicing para-snowboard usually sustained injuries within the upper limbs, probably due to inadequate protection of their most exposed body parts during falling.

The simple recommendations for healthy people and Paralympic formula competitors, indicating that judo, sambo and every martial art including teaching safe fall techniques are the suitable complementary sports, are 
insufficient. No matter that e.g. judo training, stimulates muscle strength, endurance and other motor abilities [4245]. As a sport, judo entails high risk of injuries and even death $[46,47]$.

\section{Conclusion}

Implementation of safe falling programs as an adapted physical activity for patients with visual impairment or after limb amputation may adversely affect their feeling of safety and motivation for practicing sports, tourism or other physical activities.
Physiotherapy students specializing in safe falling will contribute to a growing number of new workplaces and innovative services, both for able-bodied people and people with disabilities. Such a specialty will be essential for public health including improvement of the patient's quality of life.

\section{Conflict of interest}

There were no conflicts of interest.

\section{References}

1. WHO. Falls. [Internet]. 2019. [updated 2019; cited 2019 Nov 13]. Available from: https://www.who.int/news-room/factsheets/detail/falls

2. Yoshida S. A Global Report on Falls Prevention: Epidemiology of Falls. Geneva: WHO; 2007.

3. Guideline for the prevention of falls in older persons. American Geriatrics Society, British Geriatrics Society, and American Academy of Orthopaedic Surgeons Panel on Falls Prevention. J Am Geriatr Soc. 2001;49(5):664- 72. https://doi.org/10.1046/j.1532-5415.2001.49115.x

4. Jaskólski E, Nowacki Z. Theory, methodology and systematics of soft incidence. Part I. The theory of soft incidence. Wrocław: WSWF; 1972. (In Polish)

5. Kalina RM, Barczyński BJ, Jagiełło W, Kruszewski A, Przeździecki B, Harasymowicz J, Syska J, Szamotulska $\mathrm{K}$. Teaching of safe falling as most effective element of personal injury prevention in people regardless of gender, age and type of body build - the use of advanced information technologies to monitor the effects of education. Arch Budo, 2008; 4: 82-90.

6. Kalina RM, Barczyński BJ, Klukowski K, Langfort J, Gąsienica-Walczak B. The method to evaluate the susceptibility to injuries during the fall - validation procedure of the specific motor test. Arch Budo, 2011;7(4): 203-216.

7. Kalina A, Kalina RM, Klukowski K. Collision avoidance exercises and safe fall for rehabilitation purposes. Wychowanie Fizyczne i Zdrowotne, 1998; 1: 20-26. (In Polish)

8. Kalina RM, Kruszewski A, Jagiełło W, Włoch G. Introduction to martial arts - basics of judo. Warsaw: AWF Warsaw publisher; 2003. (In Polish)

9. Kalina RM, Barczyński BJ. EKO-AGRO-FITNESSC original author's continuous program of health-oriented and ecological education in the family, among friends or individually implemented - the premises and assumptions. Arch Budo, 2010; 6(4): 178-184.

10.Jagiełło W, Kalina RM, Klimczak J. Fun forms of martial arts in positive enhancement of all dimensions of health and survival abilities. In: Kalina RM, editor. Proceedings of the 1st World Congress on Health and Martial Arts in Interdisciplinary Approach, HMA 2015, 17-19 September 2015, Czestochowa, Poland. Warsaw: Archives of Budo; 2015. P.32-39.

11.Gąsienica-Walczak B. Motor, methodical and mental qualifications of physiotherapy students in the field of safe falling - the perspective of preventing falls of persons with visual impairments, with immobilized or amputated limb. [Doctoral dissertation]. Rzeszow: University of Rzeszow; 2018. (In Polish)

12. Wolf SJ, Kutner NG, Green RC, McNeely E. The Atlanta FICSIT Study. Two Exercise Interventions to
Reduce Frailtv in Elders. JAGS 1993; 41.329- 332. https.//doi.org/10.1111/j.1532-5415.1993.tb06713.x

13.Tinetti ME, Baker DI, McAvay G, Claus EB, Garret P, Gottschalk M, Koch ML, Trainor K, Horwitz RI. A multifactorial intervention to reduce the risk of falling among elderly older people living in the community. N. Engl. J. Med. 1994; 331(13): 821- 827. https.//doi.org/10.1056/NEJM199409293311301

14.Sattin RW, Rodriguez JG, DeVito CA, Wingo PA. Study to Assess Falls Among the Elderly (SAFE) Group. Home Environmental Hazards and the Risk of Fall Injury Events Among Community-Dwelling Older Persons. Journal of the American Geriatrics Society, 1998;46:669-76. https.//doi.org/10.1111/j.1532-5415.1998.tb03799.x

15.Roberson MC, Campbell AJ, Gardner MM, Devlin N. The effectiveness of a community-based program for reducting the incidence of falls in the elderly. a randomized trial. $J \mathrm{Am}$. Geriatr. Soc. 2002; 50: 905-911.

16.Clemson L, Cumming RG, Kendig H, Swann M, Heard $\mathrm{R}$, Taylor $\mathrm{K}$. The effectiveness of a community-based program for reducing the incidence of falls in the elderly. A randomized trial. J Am Geriatr Soc. 2004; 52(9):1487- 94. https.//doi.org/10.1111/j.1532-5415.2004.52411.x

17.Skelton D, Dinan S, Campbell M, Rutherford O. Tailored group exercise (Falls Management Exercise-FaME) reduces falls in community-dwelling older frequent fallers (an RCT). Age Ageing. 2005; 34(6):636- 39. https.//oi.org/10.1093/ageing/afi174

18. Shier V, Trieu E, Ganz DA. Implementing exercise programs to prevent falls. systematic descriptive review. Injury Epidemiology, 2016; 3: 16. https.//doi.org/10.1186/s40621-016-0081-8

19.Hill KD, Suttanon P, Lin SI, Tsang WWN, Ashari A, Hamid TAA, Farrier K, Burton E. What works in falls prevention in Asia. a systematic review and meta-analysis of randomized controlled trials. BMC Geriatrics, 2018; 18: 3. https.//doi.org/10.1186/s12877-017-0683-1

20.Dobosz D, Barczyński BJ, Kalina A, Kalina RM. The most effective and economic method of reducing death and disability associated with falls. Arch Budo, 2018; 14:239246.

21.Rauk-Kubacka A, Kubacki R, Maśliński, J, Harmaciński D, Migasiewicz J, Piepiora P. Swiss ball as a tool supporting the learning of safe smashing (ukemi) and shaping the balance of the body for trainers, sport instructors and Physical Education teachers. Arch Budo Sci Martial Art Extreme Sport, 2018; 14.

22.Toronjo-Hornillo L, DelCastillo-Andrés Ó, CamposMesa MDC, Díaz Bernier VM, Zagalaz Sánchez ML. Effect of the Safe Fall Programme on Children's Health and Safety. Dealing Proactively with Backward Falls in 
Physical Education Classes. Sustainability, 2018; 10: 1168. https.//doi.org/10.3390/su10041168

23.Kalina RM. Martial arts and self-defense training in youth defense education. Warsaw: Polish Scientific Society of Physical Culture; 1997. (In Polish)

24.Syska J, Bógdał D. The relationship between safe fall skills and comprehensive physical fitness. In: Dąbrowski A, Jasiński T, Kalina RM. Fight sports in education of children and youth - methodological perspective. Plock: College of Paweł Włodkowic; 2002. (In Polish)

25.Kalina RM, Kalina A. Theorietical and methodological aspects of teaching lower extremity amputees safe falling. Advances in Rehabilitation, 2003; 17: 71-87.

26.Kalina RM. Jagiełło W. Wiktorek P. Motor Competence in Self-Defence of Students of a Detectives' School during Their Course of Studies. Arch Budo, 2007; 3: 1-6.

27.Kalina R. Teaching how to fall safely. Przeglad Wojsk Ladowych, 1976; 5: 77-81. (In Polish)

28.Kalina RM. Multidimensional tests as a fundamental diagnostic tool in the prophylactic and therapeutic agonology - the methodological basis of personal safety (Part II. motor and psychomotor multidimensional tests). Arch Budo Sci Martial Art Extreme Sport, 2018; 14: 1-14.

29.Żiżka-Salamon D, Gąsienica-Walczak B. Acceptance and Areas of Involvement of Students of Tourism and Recreation in EKO- AGRO-FITNESSC Programme. Arch Budo, 2011; $7(2): 10-16$

30.Mroczkowski A. Motor safety of a man during a fall. Arch Budo, 2015; 11: 293-303.

31.IFAPA. International Federation of Adapted Physical Activity, IFAPA's By-Laws. [Internet]. 2004. [updated 2019; cited 2019 Nov 13]. Available from: http.//www.ifapa/imgs/ uploads/PDF/IFAPA\%20By-Laws.pdf

32.Morgulec-Adamowicz N, Kosmol A, Molik B. Adapted physical activity for physiotherapists. Warsaw: PZWL Medical Publishing House; 2014. (In Polish)

33.Kalina RM. Innovative agonology as a synonym for prophylactic and therapeutic agonology - the final impulse. Arch Budo, 2016; 12: 329-344.

34.Krzemieniecki LA, Moska W. Combat issues in literary works of Nobel Laureates for Literature an interdisciplinary perspective of martial arts bibliotherapy. Arch Budo, 2016; 12: $345-352$.

35.Kalina RM, Barczyński BJ. Mixed assessments as mental and pedagogic basis of innovative self-defence. Arch Budo, 2017; 13: 187-194.

36. Mosler D, Kalina RM. Possibilities and limitations of judo (selected martial arts) and innovative agonology in the therapy of people with mental disorders and also in widely understood public health prophylaxis. Arch Budo, 2017; 13: 211-226.
37.Klimczak J, Kalina RM. Placebo effect - the perspective of diagnosis and therapy of aggressiveness by using fun forms of martial arts during innovative agonology cognitivebehavioural sessions (case study). Arch Budo, 2019; 15: 57-66.

38.Gąsienica Walczak B, Barczyński BJ, Kalina RM. Evidencebased monitoring of the stimuli and effects of prophylaxis and kinesiotherapy based on the exercises of safe falling and avoiding collisions as a condition for optimising the prevention of body injuries in a universal sense - people with eye diseases as an example of an increased risk group. Arch Budo, 2018; 14. 10-16.

39.Molik B, MarszałekJ. The specificity of injuries in Paralympics sport. Advances in Rehabilitation, 2013;27.36-41. https.//doi.org/10.2478/rehab-2014-0020

40.Ferrara MS, Peterson CL. Injuries to Athletes With Disabilities. Identifying to Injury Patterns. Sport Med. 2000;30(2):137-43. https.//doi.org/10.2165/00007256-200030020-00006

41.Derman W, Runciman P, Jordaan E, Schwellnus M, Blauwet $\mathrm{Ch}$, Webborn $\mathrm{N}$ et al. High incidence of injuries at the Pyeongchang 2018 Paralympic Winter Games. A prospective cohort study of 6804 athlete days. Br JSports Med, 2019;0.1-6. https.//doi.org/10.1136/bjsports-2018-100170

42.Jagiełło W, Kalina RM, Tkaczuk W. Age peculiarities of speed and endurance development in young judo athletes. Biol Sport, 2001; 18(4): 281-295.

43.Jagiełło W, Kalina RM, Tkaczuk W. Development of strength abilities in children and youth. Biol Sport, 2004; 21(4): 351368.

44.Maśliński J, Witkowski K, Jatowtt A et al. Physical fitness 1112 years boys who train judo and those who do not practise sport. Arch Budo Sci Martial Art Extreme Sport, 2015; 11: 41-46.

45.Celik NM, Beyleroglu M, Soyal M, Ciris V. The effect of liquid losses in trainings during competition period on some biochemical values of u18 male judokas ( age 1517). Physical education of students, 2017;21(5):249-54. https://doi.org/10.15561/20755279.2017.0508

46.Kamitani T, Nimura Y, Nagahiro S, Miyazaki S, Tomatsu T. Catastrophic Head and Neck Injuries in Judo Players in Japan From 2003 to 2010. Am J Sports Med, 2013;41:1915-21. https.//doi.org/10.1177/0363546513490662

47.Pocecco E, Ruedl G, Stankovic N, Sterkowicz S, Del Vecchio FB, Gutiérrez-García $\mathrm{C}$, et al. Injuries in judo: a systematic literature review including suggestions for prevention. $\mathrm{Br} J$ Sports Med, 2013;47:1139-43. https.//doi.org/10.1136/bjsports-2013-092886 


\section{Information about the author:}

Gąsienica Walczak B.; http://orcid.org/0000-0001-7818-6333; bgw01@interia.pl; Podhale State College of Applied Sciences in Nowy Targ; ul.Kokoszków 71, 34-400, Nowy Targ, Poland.

\section{Cite this article as:}

Gąsienica Walczak B. Acceptance of the sense of implementing safe fall programs for people with visual impairments or after amputation of limbs - the perspective of modern adapted physical activity. Physical education of students, 2019;23(6):288296.

https://doi.org/10.15561/20755279.2019.0603

This is an Open Access article distributed under the terms of the Creative Commons Attribution License, which permits unrestricted use, distribution, and reproduction in any medium, provided the original work is properly cited http://creativecommons.org/licenses/by/4.0/deed.en

Received: 15.11.2019

Accepted: 14.12.2019; Published: 18.12.2019 